\title{
Spatial distribution and dive behavior of Gulf of Mexico Bryde's whales: potential risk of vessel strikes and fisheries interactions
}

\author{
Melissa S. Soldevilla ${ }^{1, *}$, John A. Hildebrand ${ }^{2}$, Kaitlin E. Frasier ${ }^{2}$, \\ Laura Aichinger Dias ${ }^{1,3}$, Anthony Martinez ${ }^{1}$, Keith D. Mullin ${ }^{4}$, Patricia E. Rosel ${ }^{5}$, \\ Lance P. Garrison ${ }^{1}$
}

\begin{abstract}
${ }^{1}$ Southeast Fisheries Science Center, National Oceanic and Atmospheric Administration, 75 Virginia Beach Drive, Miami, FL 33143, USA

${ }^{2}$ Scripps Institution of Oceanography, University of California, San Diego, La Jolla, CA 92037, USA

${ }^{3}$ Cooperative Institute for Marine and Atmospheric Studies, University of Miami, 4600 Rickenbacker Causeway, Miami, FL 33149, USA

${ }^{4}$ Southeast Fisheries Science Center, National Oceanic and Atmospheric Administration, 3209 Frederic Street, Pascagoula, MS 39567, USA

${ }^{5}$ Southeast Fisheries Science Center, National Oceanic and Atmospheric Administration, 646 Cajundome Blvd, Lafayette, LA 70506, USA
\end{abstract}

\begin{abstract}
Bryde's whales Balaenoptera edeni are the only resident baleen whale species in the Gulf of Mexico (GoM), where they are extremely rare, have a restricted distribution, and represent a unique evolutionary lineage. The reasons for the restricted distribution and small population size are unknown, but high levels of industrial activity in the GoM may be a major factor. We evaluated the geospatial overlap of GoM Bryde's whales with 2 industries known to impact baleen whale species: commercial shipping and commercial fisheries. We further evaluated the potential for impacts by examining the first dive behavior data collected from a kinematic tag attached to a GoM Bryde's whale for $3 \mathrm{~d}$. Vessel traffic and fishery effort are low in GoM Bryde's whale habitat compared to the rest of the northern GoM, but several shipping lanes transit through the habitat, and the reef fish bottom longline fishery exerts considerable effort within the habitat. The tagged whale exhibited diel diving behavior with diurnal deep dives and foraging lunges at or near the sea floor, and shallow nocturnal diving, with $88 \%$ of its nighttime spent near the surface within the draught depths of most large commercial vessels. Given the location of commercial shipping traffic in GoM Bryde's whale habitat, ship strikes may pose a threat to this population if the whales commonly spend time near the surface, especially at night. Also, if bottom or near-bottom feeding is a normal feeding strategy for these whales, there is potential for entanglement in bottom longline gear. Managing these threats may improve population recovery.
\end{abstract}

KEY WORDS: Balaenoptera edeni - Distribution - Acousonde $\cdot$ Kinematic tag $\cdot$ Satellite telemetry Dive behavior $\cdot$ Vessel collision · Fishery entanglement $\cdot$ Gulf of Mexico

\section{INTRODUCTION}

Bryde's whales Balaenoptera edeni are the only resident baleen whale species in the northern Gulf of Mexico (GoM) and are extremely rare, with an esti-

${ }^{*}$ Corresponding author: melissa.soldevilla@noaa.gov mated abundance of only 33 individuals (CV 1.07) in US waters in 2009 (Garrison 2016, Waring et al. 2016). Recent evidence indicates that this population represents a unique evolutionary lineage that is distinct from the 2 currently recognized Bryde's whale 
subspecies (B. e. edeni and B. e. brydei), and additionally that it exhibits very low levels of genetic diversity (Rosel \& Wilcox 2014). Taxonomic uncertainty is high for the clade of Bryde's whales and sei whales $B$. borealis; while it is certain this population represents a unique evolutionary lineage, it remains undetermined whether the GoM baleen whales are a sub-species of Bryde's whale or a unique species (Rosel \& Wilcox 2014). We refer to them as the GoM Bryde's whale until the taxonomic status of the clade can be resolved. Recent sightings data suggest that the whales currently have a restricted northeastern GoM shelf break distribution (Mullin et al. 1994, Mullin \& Fulling 2004), while their historic distribution may have been broader (e.g. Reeves et al. 2011). The extremely low population abundance, unique evolutionary lineage, low genetic diversity, restricted range, and potential range contraction of GoM Bryde's whales present conservation concerns (Rosel \& Wilcox 2014), and this population is currently being evaluated for potential listing as endangered under the US Endangered Species Act (Federal Register 80 FR 18343).

Limited information is available to determine why this population has its current distribution and abundance or what risks the whales face today. Many large whale species were reduced to low population numbers due to historical whaling, and for some species, contemporary human industrial activities prevent the species from recovering (Thomas et al. 2016). While whaling vessels occasionally hunted Bryde's whales, sperm whales Physeter macrocephalus were the main target in the GoM (Reeves et al. 2011), and the population level impacts of historic whaling on GoM Bryde's whales are unknown. Regardless of why the population is at its current small size and restricted distribution, impacts from human industrial activities may be preventing population growth and distributional expansion. The GoM is highly industrialized, with activities including oil and gas exploration and extraction, fisheries, and shipping. This already small population was the most impacted offshore cetacean during the extensive Deepwater Horizon oil spill in 2010, with an estimated $48 \%$ of their habitat oiled and an estimated $22 \%$ population decline from their pre-spill population size as a result of the spill (DWH MMIQT 2015). These impacts highlight that the potential risks of all GoM industrial activities to this small population need to be better understood to improve their chances of recovering from these losses.

Vessel collisions and fishery gear entanglements are the 2 main industrial threats currently impacting most baleen whales (Knowlton \& Kraus 2001, Laist et al. 2001, Read et al. 2006, Thomas et al. 2016). True numbers of whale interactions with fisheries and vessels are typically underestimated, as fishery observer programs are often limited in scope and miss rare events, while stranding records and public reports only provide minimum counts (Heyning \& Dahlheim 1990, Kraus et al. 2005). Further, species representation in stranding records and public reports is usually skewed toward coastally distributed species, both due to higher densities of anthropogenic activities near coasts, and higher likelihood that carcasses will drift to shore, be reported, and be in fresh enough condition to be evaluated for signs of human interactions. Both fishery gear entanglements and vessel collisions may be documented relatively infrequently for a baleen whale species, but may still be considered a major threat, particularly for small populations which are generally more vulnerable to low levels of human-caused mortality (e.g. Read et al. 2006).

Vessel collisions may be an important source of anthropogenic mortality for GoM Bryde's whales. Vessel collisions may lead to mortality or serious injury from either blunt force trauma when the hull of the vessel collides with a whale or sharp force trauma from propeller cuts. Lethality of blunt force trauma increases with increasing vessel speed and with greater vessel size (Laist et al. 2001, Jensen \& Silber 2004, Vanderlaan \& Taggart 2007). Lethality of sharp trauma depends on animal size, cut penetration depth, and cut location (Andersen et al. 2008, Campbell-Malone et al. 2008). At least 25 Bryde's whales vessel collision mortalities have been documented worldwide (Jensen \& Silber 2004, Carrillo \& Ritter 2010, Waring et al. 2012, Carretta et al. 2014, Constantine et al. 2015), with $68 \%$ of these occurring in Hauraki Gulf, New Zealand (Constantine et al. 2015), where the population has a nearshore distribution. Generally, Bryde's whale vessel collision mortalities are less commonly reported than whale species with more coastal distributions (e.g. Van Waerebeek et al. 2007, Van Waerebeek \& Leaper 2008), likely because many go undetected or unreported when they occur in remote areas or when carcasses sink or drift out to sea (e.g. Jensen \& Silber 2004). One documented Bryde's whale ship strike mortality occurred in the GoM when a commercial vessel brought a dead lactating female GoM Bryde's whale into the Tampa Bay, Florida (FL), harbor on its bow in 2009 (NOAA MMHSRP 2015).

Fishery entanglements may also be an important source of mortality for GoM Bryde's whales. Fishery gear entanglements may lead to acute mortality from 
drowning or to more protracted mortality caused by injury or impaired foraging and subsequent starvation, infection, hemorrhage, or debilitation (Cassoff et al. 2011). Marine mammals may swim away mortally injured, sometimes with gear still attached; these injuries and deaths are not observed and accounted for in bycatch statistics (Reeves et al. 2013). High rates of entanglement scarring observed on living baleen whales indicate that these cryptic incidents occur much more frequently than indicated by statistics of known bycatch mortality (Robbins \& Mattila 2004, Knowlton et al. 2012). Globally, Bryde's whales have been entangled in many commercial fishery gear types, including gillnets (Reeves et al. 2013, Moazzam \& Nawaz 2014), a non-fishery shark net (Meÿer et al. 2011), pot/traps (Groom \& Coughran 2012), purse-seines (Western and Central Pacific Fisheries Commission 2012, Berkenbusch et al. 2013), and mussel aquaculture gear (Lloyd 2003, Constantine et al. 2015). Bryde's whales, which are not common or abundant in US waters, are not commonly observed by fishery observer programs in US waters (Forney et al. 2000, 2011, Carretta et al. 2008, 2013, Keene \& Beerkircher 2015). Between 1994 and 2009, only 1 Bryde's whale was observed entangled in shallow-set longline gear off Hawaii in 2005 (Forney et al. 2011). Several cases of fishery interactions have been documented for GoM Bryde's whales based on stranding data, including (1) a Bryde's whale mistakenly identified as a sei whale that stranded on Anclote Key, FL (north of Tampa Bay), in 1974 entangled in polypropylene line (Mead 1977), (2) a GoM Bryde's whale entangled in unidentified fishing line with subsequent live release (Blaylock et al. 1995), and (3) a well-documented trap/pot entanglement mortality in 2003 of a severely emaciated male GoM Bryde's whale that washed ashore in North Carolina with severe entanglement of the mouth (Cassoff et al. 2011, Rosel \& Wilcox 2014).

In this study, we evaluated the spatial distribution and dive behavior of GoM Bryde's whales and the potential risk of interactions with shipping and commercial fisheries based on the behavioral ecology of the whales. We present the spatial distribution of GoM Bryde's whales in the northern GoM based on visual ship-based surveys over $24 \mathrm{yr}$, the first data on the movement patterns of a GoM Bryde's whale obtained from a satellite-telemetry tag, and the first data on the dive behavior of a GoM Bryde's whale obtained from a suction-cup kinematic tag. Additionally, we compiled and evaluated data on the spatial distribution and effort levels of 2 anthropogenic activities known to result in mortality in GoM Bryde's whales: commercial shipping traffic for its potential collision risk and fishery effort for its potential entanglement risk. For activities which may pose a threat, we discuss research and mitigation measures that may be effective for evaluating and reducing risk.

\section{MATERIALS AND METHODS}

\section{GoM Bryde's whale distribution}

The geospatial distribution of GoM Bryde's whales throughout US waters of the GoM was ascertained from 25 NOAA Southeast Fisheries Science Center (SEFSC) ship-based line-transect surveys conducted between 1992 and 2015 to estimate the abundance and distribution of cetaceans in the continental shelf and oceanic waters of the GoM and 1 additional linetransect survey transited through GoM waters on its return to port in 2011 (Table 1). Visual surveys following standard line-transect methods (e.g. Burnham et al. 1980, Buckland et al. 1993, Barlow 1995) were conducted concurrent with ichthyoplankton sampling surveys (1992-2001) or as dedicated cetacean cruises (2003-2015) (Mullin \& Fulling 2004, Mullin 2007). Line-transect data were collected while transiting at 10 knots $\left(18.5 \mathrm{~km} \mathrm{~h}^{-1}\right)$ along predefined tracklines during daylight hours in good weather (i.e. Beaufort state $<6$, no rain, fog, haze, or lightning) using $25 \times 150 \mathrm{~mm}$ 'Bigeye' binoculars mounted on the ship's flying bridge. Differences in survey objectives among years affected the distribution of effort between shelf and oceanic waters and between the western and eastern GoM. However, as a composite, survey effort throughout waters of the US Exclusive Economic Zone (EEZ) was comprehensive enough to provide a picture of GoM Bryde's whale distribution (Fig. 1a). During these surveys, baleen whale sightings were identified as (1) Bryde's whales when the 3 rostral ridges and other identifying characteristics were observed or a biopsy was obtained and confirmed the species, (2) Bryde's or sei whales when the identifying features observed were not enough to reliably exclude either of the 2 species and biopsy samples could not be obtained to confirm species, or (3) unidentified balaenopterid when features observed were unreliable or insufficient to determine the species. Total survey effort density was calculated from survey tracks over a $10 \times 10 \mathrm{~km}$ grid, and survey effort density and baleen whale sighting locations were mapped in QGIS v2.10.1-Pisa (www. qgis.org). A biologically important area (BIA; Fig. 1b) was delineated from the De Soto Canyon along the 
Table 1. Ship-based line-transect survey effort in the northern Gulf of Mexico (GoM) from 1992 to 2015. Total trackline surveyed while observers were on effort is presented for each survey and for that which occurred within the biologically important area (BIA) boundaries. Annual numbers of sightings, with the total annual numbers of animals sighted in parentheses, are presented for confirmed GoM Bryde's whale Balaenoptera edeni sightings and unidentified balaenopterid sightings each year. EEZ: US exclusive economic zone

\begin{tabular}{|c|c|c|c|c|c|c|c|}
\hline \multirow[t]{2}{*}{ Year } & \multirow[t]{2}{*}{ Surveys } & \multicolumn{2}{|c|}{ On-effort trackline $(\mathrm{km})$} & \multicolumn{2}{|c|}{ Bryde's whale sightings } & \multicolumn{2}{|c|}{ Balaenopterid sightings } \\
\hline & & Total EEZ & BIA & Total EEZ & BIA & Total EEZ & BIA \\
\hline 1992 & 1 & 6203 & 253 & $1(4)$ & $1(4)$ & $2(3)$ & $1(1)$ \\
\hline 1993 & 2 & 10241 & 131 & 0 & 0 & 0 & 0 \\
\hline 1994 & 2 & 8746 & 811 & 0 & 0 & $2(2)$ & $2(2)$ \\
\hline 1996 & 1 & 6403 & 765 & $2(6)$ & $2(6)$ & $1(1)$ & $1(1)$ \\
\hline 1997 & 1 & 6378 & 800 & $1(2)$ & $1(2)$ & 0 & 0 \\
\hline 1998 & 1 & 720 & 64 & 0 & 0 & 0 & 0 \\
\hline 1999 & 1 & 4612 & 269 & $2(3)$ & $2(3)$ & 0 & 0 \\
\hline 2000 & 3 & 7047 & 402 & $3(7)$ & $3(7)$ & 0 & 0 \\
\hline 2001 & 2 & 7291 & 597 & 0 & 0 & 1 (1) & $1(1)$ \\
\hline 2003 & 1 & 6971 & 320 & 0 & 0 & 0 & 0 \\
\hline 2004 & 1 & 6915 & 457 & $4(7)$ & $4(7)$ & $1(1)$ & $1(1)$ \\
\hline 2007 & 1 & 5009 & 968 & $3(13)$ & $3(13)$ & 0 & 0 \\
\hline 2008 & 1 & 1423 & 152 & 0.0 & 0.0 & 0 & 0 \\
\hline 2009 & 1 & 4591 & 117 & $3(8)$ & $3(8)$ & 0 & 0 \\
\hline 2010 & 3 & 6523 & 1912 & $6(11)$ & $4(4)$ & $1(1)$ & $1(1)$ \\
\hline 2011 & 1 & 492 & 250 & 4 (19) & 4 (19) & 0 & 0 \\
\hline 2012 & 1 & 4145 & 468 & $2(5)$ & $2(5)$ & 0 & 0 \\
\hline 2014 & 1 & 2405 & 0 & 0 & 0 & 0 & 0 \\
\hline 2015 & 1 & 3538 & 1336 & $19(27)$ & $18(26)$ & 0 & 0 \\
\hline Total & & 99652 & 10072 & 50 (112) & 47 (104) & $8(9)$ & $7(7)$ \\
\hline
\end{tabular}

shelf break to the southeast to highlight the importance of this region to the small resident GoM Bryde's whale population and to aid in future geospatial management of cetaceans (LaBrecque et al. 2015). The $23559 \mathrm{~km}^{2}$ area covers waters between 100 and $300 \mathrm{~m}$ deep from approximately south of Pensacola to approximately west of Fort Meyers, FL (LaBrecque et al. 2015). This BIA was overlaid on survey effort density and sightings maps to evaluate GoM Bryde's whale geospatial distribution with respect to the BIA boundaries.

\section{GoM Bryde's whale movement patterns}

To document whale movement patterns, a satellite telemetry tag was deployed on a GoM Bryde's whale during a SEFSC cetacean survey on the NOAA vessel 'Gordon Gunter' in October 2010. A low-impact minimally percutaneous electronic transmitter (LIMPET) tag with a SPOT5 location-only Argos transmitter (Wildlife Computers; Andrews et al. 2008) was attached remotely via crossbow following established cetacean tagging protocols using a $7 \mathrm{~m}$ inflatable vessel, the 'R3.' Photographs were taken during the tagging efforts to document tag placement and the condition of the whale, a biopsy sample was taken for individual and sex identification, and any reactions to the tag deployment were noted.

Transmitter battery life was expected to be $75 \mathrm{~d}$. Geographic locations of transmitters were estimated by Service Argos (Collected Localization Satellites America) using the non-linear least-squares method based on the Doppler shift in the tag transmission frequency as the satellite passed overhead (Argos User's Manual, www.argos-system.org/manual/). Only highest quality Argos locations, those of class $2(500 \mathrm{~m}$ accuracy) and class 3 (250 $\mathrm{m}$ accuracy), were retained for further analyses. Following quality filtering, greatcircle distances were calculated between consecutive locations, and rates of travel $\left(\mathrm{km} \mathrm{h}^{-1}\right)$ were calculated. These rates represent sustained rates of travel over approximately half-day- to day-long periods and should be considered minimum estimates. A map to assess movement patterns and usage area was produced in QGIS using the filtered localizations.

\section{GoM Bryde's whale dive behavior}

To document whale dive behavior, a multi-sensor Acousonde tag was attached with suction cups to a 

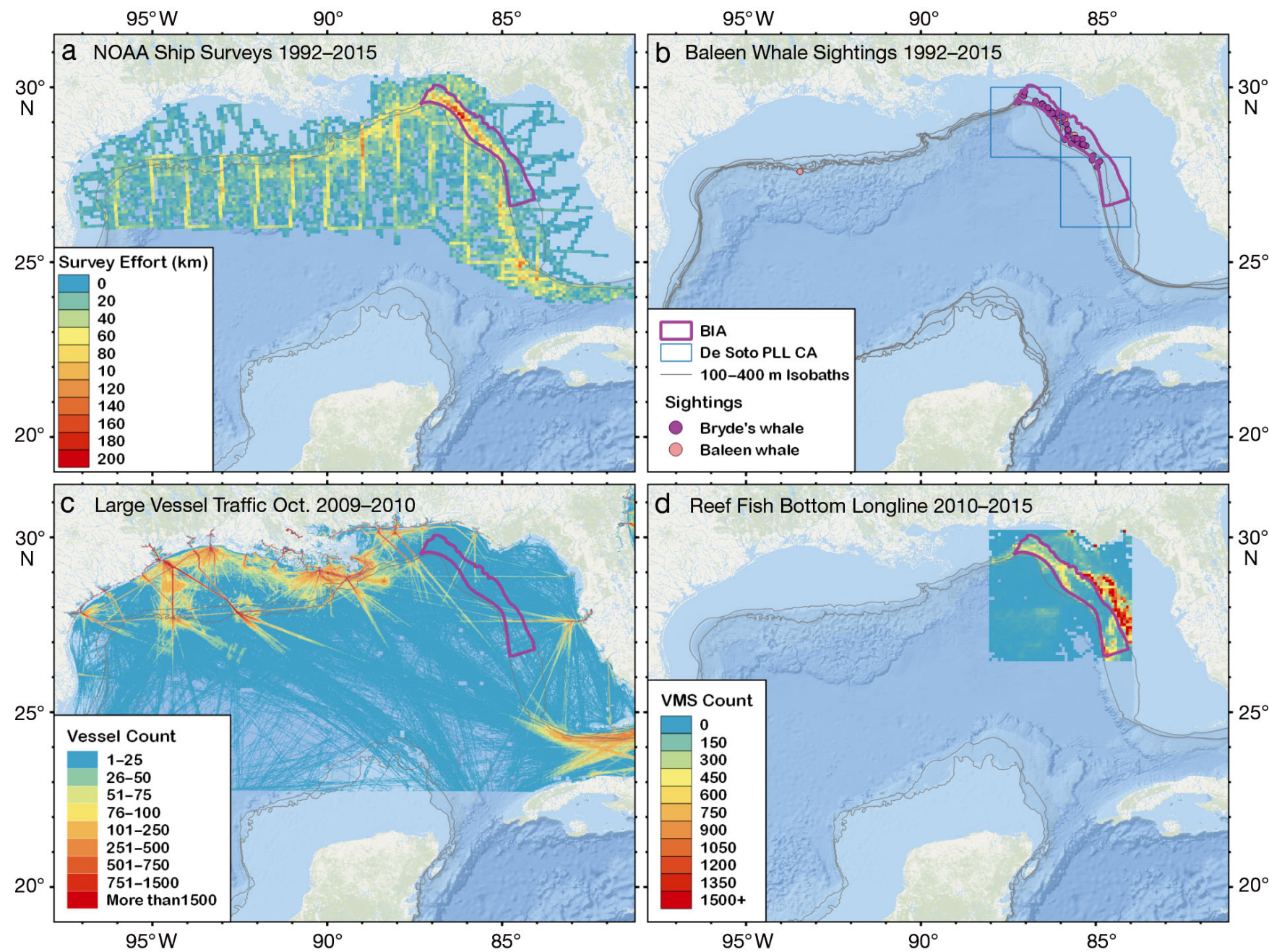

Fig. 1. Geospatial distribution of (a) National Marine Fisheries Service, Southeast Fisheries Science Center (NMFS SEFSC) cetacean survey effort per $100 \mathrm{~km}^{2}$, (b) GoM Bryde's whale Balaenoptera edeni and baleen whale sightings, (c) large commercial vessel traffic, and (d) approximation of reef fish bottom longline effort. Gulf of Mexico (GoM) Bryde's whale biologically important area (BIA; purple polygon) boundaries are overlaid, the 100 and $400 \mathrm{~m}$ isobaths are included in (a), (c), and (d), and the 100, 200, 300, and $400 \mathrm{~m}$ isobaths are included in (b). The De Soto Canyon pelagic longline closed area (PLL CA), where pelagic longline fishing is excluded year-round, is overlaid in (b). Northern GoM vessel traffic density is based on Automated Information Systems (AIS) transponder transmissions (www.marinecadastre.gov) mapped in $100 \mathrm{~m}$ grid cells. Bottom longline effort is approximated as Vessel Monitoring System (VMS) transmission points (Rivero 2015), mapped at 5 arcmin grid cell resolution. Maps were created in QGIS

GoM Bryde's whale during a SEFSC Bryde's whale survey on the 'Gordon Gunter' in September 2015. A GoM Bryde's whale sighted in good weather conditions was approached using the 'R3' and standard protocols, and a Model B003B Acousonde (Greenridge Sciences) suction-cup tag was attached using a pole deployment method. The whale was tracked by observers on the 'Gordon Gunter' throughout daylight hours visually and via VHF receiver to ensure tag recovery and obtain surface location fixes for later dive track reconstruction. Following nightfall, a set route was followed to attempt to relocate the tagged whale and recover the tag. The VHF receiver allowed the tag to be detected when it was above the water surface, and the vessel was maneuvered to track and recover the tag after it detached from the whale.

The tag instrumentation included temperature and pressure sensors, triaxial magnetometers and accelerometers, a compass, and a hydrophone. All nonacoustic sensors were sampled at $5 \mathrm{~Hz}$, while acoustic data were sampled at $9110 \mathrm{~Hz}$. Tag data were analyzed with customized routines using Matlab (Mathworks). Because the pressure sensor of the 
Acousonde 3B is affected by temperature, a correction factor was determined empirically for periods when the whale was at the surface as:

$$
P_{\text {corr }}=P_{\text {orig }}+35.87-0.45 \times T
$$

where $P_{\text {corr }}$ is the temperature-corrected pressure in dBars, $P_{\text {orig }}$ is the original measured pressure, and $T$ is the measured temperature in ${ }^{\circ} \mathrm{C}$. This correction was applied to the entire dataset. To examine diel differences in dive behavior, dive data were divided into day and night periods, based on sunrise and sunset times obtained from the US Naval Observatory (http://aa.usno.navy.mil). Proportions of time spent in $5 \mathrm{~m}$ depth bins were determined. Maximum drafts of commercial ships extend to $15 \mathrm{~m}$ depth, and whales are at risk of collision with ships when dive depths are within the 0 to $15 \mathrm{~m}$ depth range (e.g. Constantine et al. 2015). The cumulative proportion of time in $5 \mathrm{~m}$ depth bins was calculated to determine how much time this whale spent within $15 \mathrm{~m}$ of the surface. Only the 2dimensional dive data are presented in this study; acoustic behavior and 3-D dive behavior are the topic of a future study.

\section{Geospatial distribution of commercial shipping}

To evaluate the geospatial overlap of commercial vessel traffic with GoM Bryde's whale distributions/ habitat, commercial vessel density data based on automatic identification system (AIS) output were obtained from the NOAA Office of Coast Survey through marinecadastre.gov (BOEM, NOAA 2015; data can be downloaded from ftp://ftp.coast.noaa. gov/pub/MSP/AIS/CommercialVesselDensityOctober 2009_2010National.zip). These data represent the total number of vessel transits $\mathrm{km}^{-2}$ from October 2009 to October 2010 and provide insight into macroscale commercial traffic patterns. These data represent the majority of large, commercial vessel traffic; AIS transmissions are required for all ships of 300 gross tons or more, for passenger ships and tankers of 150 gross tons or more, for commercial vessels $\geq 20 \mathrm{~m}$ (65 feet) in length (excluding fishing and passenger vessels with fewer than 150 passengers), and for towing vessels greater than $8 \mathrm{~m}$ (26 feet) in length (for data caveats, see the Supplement at www.int-res. com/articles/suppl/n032p533_supp.pdf). Vessel transit densities were mapped in QGIS and overlaid with the Bryde's whale BIA to evaluate geospatial distribution and quantify minimum transit densities throughout the GoM and the BIA.

\section{Geospatial distribution of commercial fisheries}

Thirteen commercial fisheries with the potential to interact with cetaceans operate in the US waters of the northern GoM (Waring et al. 2014). These fisheries were preliminarily reviewed for gear types and general spatial distributions that indicated the potential to interact with GoM Bryde's whales (Rosel et al. 2016). Three fisheries met these criteria: (1) the Atlantic Ocean, Caribbean, Gulf of Mexico large pelagics longline fishery (described by Garrison 2007); (2) the GoM shark bottom longline/hook-and-line fishery (described by Hale \& Carlson 2007, Hale et al. 2010), and (3) the GoM snapper-grouper and other reef fish bottom longline/hook-and-line fishery (described by Scott-Denton et al. 2011).

For the pelagic longline fishery, the spatial distribution and the total annual effort based on selfreported daily fishing effort was obtained from the Atlantic Large Pelagics Logbook database maintained by the SEFSC (Maiello 2015). The fishery logbook system requires vessel captains to report daily fishing effort, gear characteristics, and commercial catch (Yeung 1999). Self-reported effort is assumed to be representative of the actual effort expended by the US large pelagics longline fleet. All individual set locations coded as using pelagic longline gear over the time period 2005 to 2013 were mapped in QGIS, and total annual effort was quantified as number of sets $\mathrm{yr}^{-1}$ occurring both throughout the GoM and within the Bryde's whale BIA.

For the bottom longline fisheries, vessel monitoring system (VMS) data provide geospatial distribution of the total fishery, bottom longline logbook data provide total annual fishing effort, and observer program data provide geospatial distribution and fishing effort for a subset of the data. These 3 datasets were combined to evaluate the geospatial distribution of the fishery in the northeastern GoM, the total annual effort throughout the GoM, and the estimated total annual effort within the BIA. Hourly locations of US commercial fishing vessels carrying a permit associated with bottom longline fisheries were obtained from VMS data transmissions collected by the SEFSC (Rivero 2015) for the 2006 to 2015 time frame and for the region between 88.0 and $84.0^{\circ} \mathrm{W}$ and between 26.5 and $30.5^{\circ} \mathrm{N}$, the area near the GoM Bryde's whale BIA. In the GoM, only the reef fish and large pelagics longline fisheries require the use of VMS instrumentation; a subset of vessels holding these permits additionally carry a reef fish bottom longline endorsement or a shark-directed permit indicating they fish with bottom-longline gear (see the Supple- 
ment for data caveats). Locations of vessels carrying either (1) a reef fish bottom longline endorsement in addition to a reef fish permit or (2) a shark-directed permit in addition to either a reef fish or large pelagics longline permit were extracted. A total of 409371 records were extracted between 26 May 2010 and 31 December 2015 for vessels carrying the reef fish bottom longline endorsement in addition to a reef fish permit. A total of 622332 records were extracted from 5 January 2006 to 31 December 2015 for vessels carrying a shark-directed permit in addition to either a reef fish or large pelagics longline permit. The VMS point locations were aggregated to a 5 arc min grid using the Generic Mapping Tools software (gmt.soest.hawaii.edu). These gridded data were then mapped in QGIS and overlaid with the BIA to evaluate spatial overlap of the fisheries with GoM Bryde's whale habitat.

VMS maps provide an indication of where there may be geospatial overlap in bottom-longline fishery effort and GoM Bryde's whale occurrence, but do not provide information on total annual fishery effort. The total annual effort of the GoM reef fish and shark bottom longline fisheries based on self-reported fishing effort per trip was obtained from the Southeast Coastal Logbook database maintained by the SEFSC (Gloekner \& Turner 2016) for the 2007 to 2015 time period. Selfreported effort is assumed to be representative of the actual effort expended by the bottom longline fleet. To estimate the total annual bottom-longline effort occurring within the Bryde's whale BIA, bottom-longline set locations and fishing effort of the random subset of trips observed by fishery observer programs were obtained from the SEFSC reef fish observer program from 2007 to 2016, and from the SEFSC sharkdirected fishery observer program from 1994 to 2015. Observed bottom longline set locations were mapped in QGIS, and locations occurring within the BIA were extracted and quantified to determine the annual number of observed sets within the BIA. For each year from 2007 to 2015, total annual effort in the BIA was estimated as the number of observed sets occurring in the BIA divided by the proportion of observed sets to total sets throughout the US waters of the GoM.

\section{RESULTS}

\section{GoM Bryde's whale distribution}

From 1992 to 2015, the SEFSC surveyed a total of $99652 \mathrm{~km}$ of trackline by ship throughout the US waters of the GoM, with annual survey effort ranging from 720 to $10241 \mathrm{~km}$. During this period, there were a total of 50 sightings of 112 GoM Bryde's whales and 8 sightings of 9 unidentified balaenopterid whales (including those identified as either Bryde's or sei whales). These numbers only indicate the total numbers of whales sighted over the study duration, not individual whales, as a photo-identification study was not conducted and it is probable individuals were resighted throughout the study. While effort was extensive throughout US EEZ waters of the northern GoM (Fig. 1a), all verified Bryde's whale sightings were limited to the region between the 100 and $400 \mathrm{~m}$ isobaths in the northeastern GoM from south of Pascagoula, Mississippi, to west of Tampa, FL (Fig. 1b). The minimum, median, and maximum water depths of verified Bryde's whale sightings were 185, 221 , and $352 \mathrm{~m}$, respectively. Of the total survey effort in US waters, $10.1 \%$ of the effort occurred within the BIA region, while $92.9 \%$ of verified Bryde's whales occurred within the BIA. The remaining verified sightings occurred just outside of this region, either in slightly deeper waters or just west of the northern boundary (Table 1). Most of the unidentified balaenopterid whales also occurred within this region $(78 \%$, Table 1), except for 1 sighting in 1992 of 2 Bryde's or sei whales in the northwestern GoM near the Flower Garden Banks (Fig. 1b). No sightings occurred within the southern-most extent of the BIA in the region from west of Fort Meyers to west of Tampa, FL.

\section{GoM Bryde's whale movement patterns}

On 11 October 2010 at 15:08 h Central Daylight Time (CDT), a GoM Bryde's whale at $29.587^{\circ} \mathrm{N}$ and $87.193^{\circ} \mathrm{W}$ was tagged using remote-deployment methods, with the satellite telemetry tag attached just below the base of the whale's dorsal fin. Minimal adverse reaction to the tagging was observed. Concurrent remote biopsy sampling indicated the whale was female. The satellite tag transmitted locations until 12 November 2010, a period of 33 d. During this time, 52 high-quality location fixes covered a minimum track length of $780 \mathrm{~km}$ (Fig. 2). The satellitetagged whale remained within a $280.4 \mathrm{~km}^{2}$ area near the De Soto Canyon for the $8 \mathrm{~d}$ period from 12 October to the morning of 19 October 2010. A minimum of $164 \mathrm{~km}$ were transited over this period at an average sustained rate of travel of $1.5 \mathrm{~km} \mathrm{~h}^{-1}$. Over the next $3 \mathrm{~d}$, the whale traveled a minimum of $237 \mathrm{~km}$ southeast at an average sustained rate of $3.6 \mathrm{~km} \mathrm{~h}^{-1}$, staying within the 200-300 $\mathrm{m}$ isobaths, until the morning of 22 October, when the whale turned around and 


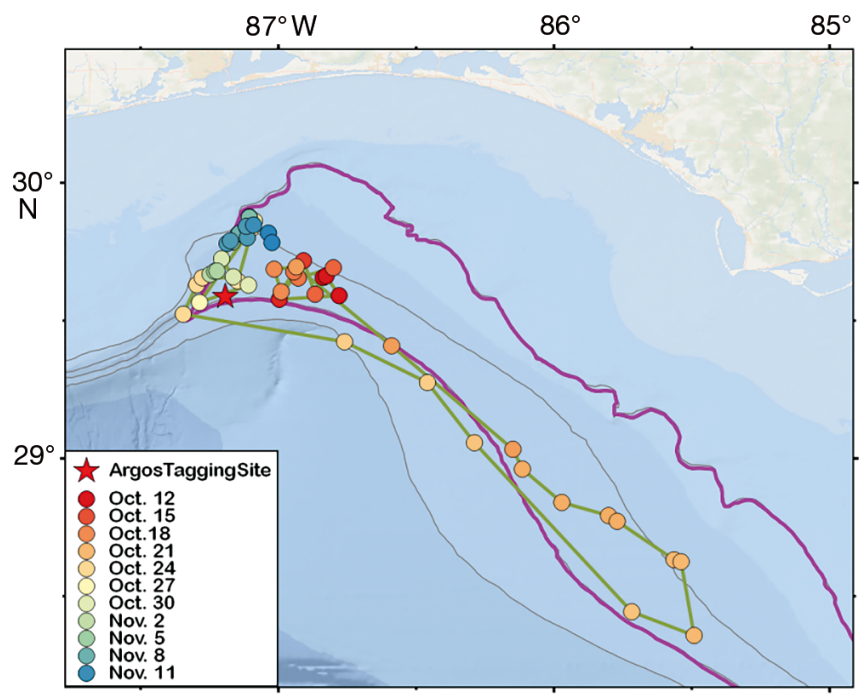

Fig. 2. Track of satellite-tagged GoM Bryde's whale Balaenoptera edeni for full transmission period from 11 October to 12 November 2010. Tag locations are color coded by date, and the site where the tag was deployed on the whale is indicated by a star. The whale remained within or just beyond the edges of the biologically important area (BIA; purple polygon), and between the 100 and $400 \mathrm{~m}$ isobaths $(100,200$, 300 , and $400 \mathrm{~m}$ isobaths are shown) throughout the $33 \mathrm{~d}$ of tracking

transited a minimum of $245 \mathrm{~km}$ northwest at an average sustained rate of $4.0 \mathrm{~km} \mathrm{~h}^{-1}$ to return to the region just north of the De Soto Canyon, arriving on the morning of 24 October 2010. The whale remained within a $487.3 \mathrm{~km}^{2}$ area in this region for the next $20 \mathrm{~d}$ until the tag's final transmission on 12 November at 20:10 h CDT. During this period, the whale traveled a minimum of $215.6 \mathrm{~km}$ at an average sustained rate of $1.2 \mathrm{~km} \mathrm{~h}^{-1}$. The average $( \pm \mathrm{SD})$ sustained rate of travel over the entire $33 \mathrm{~d}$ period was $2.0 \pm 1.9 \mathrm{~km} \mathrm{~h}^{-1}$, with a highest sustained rate of travel of $6.3 \mathrm{~km} \mathrm{~h}^{-1}$. Over the $33 \mathrm{~d}$ of transmissions, the whale spent $87.5 \%$ of days in a $1083.9 \mathrm{~km}^{2}$ area just north of the De Soto Canyon, and all of the whale's transmissions occurred within or just beyond the $300 \mathrm{~m}$ boundary of the BIA (Fig. 2).

\section{GoM Bryde's whale dive behavior}

On 20 September 2015 at 07:30 h CDT, a GoM Bryde's whale was sighted at $29.261^{\circ} \mathrm{N}$ and $86.268^{\circ} \mathrm{W}$ by the visual team aboard the 'Gordon Gunter.' At 9:25 CDT, an Acousonde 3B acoustic and kinematic data-logging, suction-cup tag was attached to the whale using a $3 \mathrm{~m}$ pole. The tag was attached during a single close-approach, and an approximately $100 \mathrm{~m}$ range was kept between the 'R3' and the animal for observation following the attachment. No adverse reaction to the tagging was observed. A concurrent biopsy sample was not obtained; the sex of this whale is undetermined. The whale was followed by visual observers on the 'Gordon Gunter' until sun-down, and throughout this observation period, this individual was associated with a smaller whale. Although the animals were associated in a pairing, the size difference and behavior did not suggest that the smaller animal was a dependent calf. Water depth at the tagging location was $255 \mathrm{~m}$. The tag remained on the animal for $63.85 \mathrm{~h}$, an extended period of time compared to typical suction-cup tag deployments of 5 to $15 \mathrm{~h}$ durations. The tag was recovered at 13:41 h CDT on 23 September 2015, $12.5 \mathrm{~h}$ after falling off the whale and $20.1 \mathrm{~km}$ from the initial tag site in $310 \mathrm{~m}$ water depth.

Throughout the $2.7 \mathrm{~d}$ tagging period, the animal exhibited a stereotypical diel dive pattern with deep dives $(>70 \mathrm{~m})$ throughout the day time and shallow dives $(<30 \mathrm{~m})$ at night (Fig. 3a). A total of 123 deep dives were recorded, only 4 of which occurred during nighttime. During the daytime, the tagged animal dove to depths as great as $271 \mathrm{~m}$, with foraging lunges apparent at the deepest parts of dives indicating the animal was likely foraging at or just above the bottom (Fig. 3b). Presumed foraging lunges were identified by stereotypical concurrent changes in pitch, roll, and depth associated with brief increases in broadband flow noise (e.g. Goldbogen et al. 2006). During the nighttime, the whale stayed close to the surface, typically making shallow dives (Fig. 3c) with occasional dives $(n=20)$ between 30 and $150 \mathrm{~m}$. The 3 deepest nighttime dives (125-150 m) occurred just following sunset or just prior to sunrise. During daylight hours and nighttime hours, respectively, this whale spent 47 and $88 \%$ of its time within $15 \mathrm{~m}$ of the surface (Fig. 3d,e), with $70 \%$ of total time spent within $15 \mathrm{~m}$ of the surface.

\section{Geospatial distribution of commercial shipping}

Throughout the GoM, the numbers of vessel transits $\mathrm{km}^{-2}$ are highest in shipping lanes near ports and around oil platforms, and major traffic lanes can be discerned (Fig. 1c). Vessel densities tend to be higher in the northwestern GoM, with more than 1500 vessel transits $\mathrm{km}^{-2} \mathrm{yr}^{-1}$ in some regions, particularly near the Port of South Louisiana, Louisiana (LA) and the Port of Houston, Texas (TX). While vessel densities in the northeastern GoM are not as high, several shipping lanes cross through the GoM Bryde's whale 

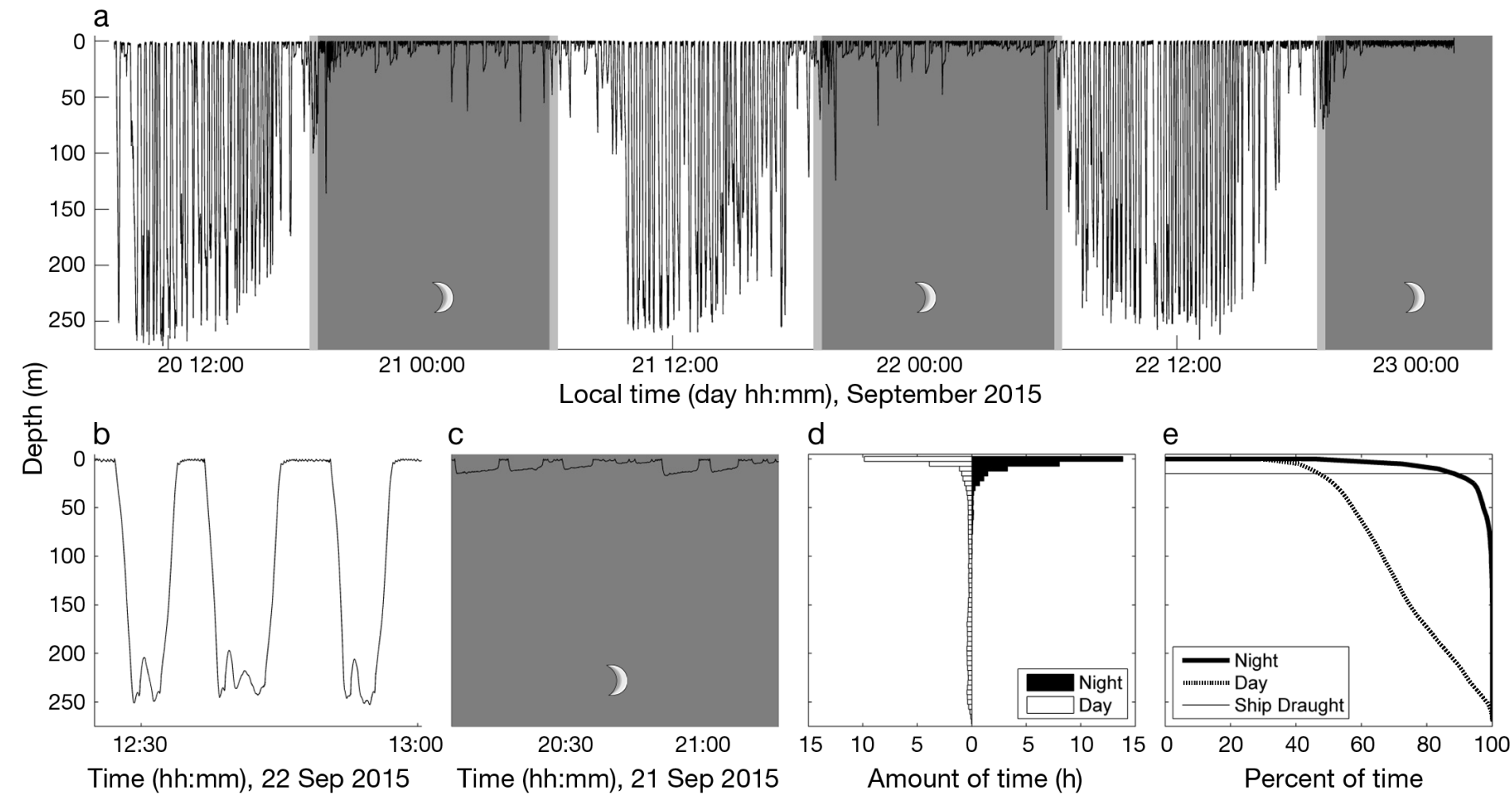

Fig. 3. Dive behavior of a GoM Bryde's whale Balaenoptera edeni tagged with an Acousonde 3B kinematic behavioral tag. (a) The time-depth profile over the course of the $2.7 \mathrm{~d}$ deployment shows deep daytime dives and shallow nighttime dives. Shorter time periods showing (b) deep daytime dives and (c) shallow nighttime dives highlight the diel difference and the foraging lunge behavior during the day. (d) Time spent in $5 \mathrm{~m}$ depth bins. (e) The cumulative distribution of time spent in depth bins during day and night highlights the high proportion of time spent in shallow waters, especially at night. The maximum ship draught of $15 \mathrm{~m}$ is indicated in panel (e) for reference

BIA, and moderate vessel densities are apparent in some portions of their habitat. These offshore vessel densities are likely biased low given the distance from port-based AIS receivers. The ports associated with these lanes are (1) the Port of Panama City, FL, (2) the Port of Tampa, FL, (3) Port Manatee, FL, and (4) ports at Crystal River, FL. From October 2009 to $2010,98.5 \%$ of the BIA waters averaged fewer than 1 vessel transit $\mathrm{wk}^{-1}$ (range: 0-50 transits $\mathrm{km}^{-2} \mathrm{yr}^{-1}$ ), while the remaining $1.4 \%$ of the BIA averaged between 1 transit $\mathrm{wk}^{-1}$ to 2 transits $\mathrm{d}^{-1}$ (range: 51-500 transits $\mathrm{km}^{-2} \mathrm{yr}^{-1}$ ). Actual numbers of transits are probably higher in this area, as AIS transmissions are likely missed due to distance from ports, and AIS transmissions are not required for non-commercial, small commercial, and military vessels.

\section{Geospatial distribution of commercial fisheries}

Throughout the GoM from 2005 to 2013, a total of 29655 pelagic longline sets were reported to the large pelagics longline logbook program for an an- nual average $( \pm$ SD) of $3295 \pm 952$ sets. This average includes 2010 and 2011, which had an unusually low number of sets as a result of the Deepwater Horizon oil spill. The geospatial distribution of sets includes offshore waters deeper than $200 \mathrm{~m}$, with the exception of the De Soto Canyon pelagic longline closed areas, which have been closed year-round to pelagic longline fishing gear since 2000 to protect juvenile swordfish (Highly Migratory Species Atlantic Tunas, Swordfish, and Sharks Fishery Management Plan amendment, Federal register 65 FR 47214). Approximately $2 / 3$ of the GoM Bryde's whale BIA overlaps with this closed area, reducing the area of overlap with pelagic longline fishing to $1 / 3$ of the BIA (Fig. 1b). During the 9 yr period, 95 sets occurred in the GoM Bryde's whale BIA, with an annual average of $10.6 \pm$ 9.7 sets. The fishery typically operates in waters deeper than $300 \mathrm{~m}$, and a total of 620 sets occurred in the deeper waters just beyond the BIA to the northeast of where the De Soto Canyon closed areas converge. Effort throughout the GoM has remained reasonably constant since 2005 (with the exception of 2010-2011); however, some effort appears to be shift- 
ing into the region northeast of the closed areas in recent years. Between 2005 and 2008, the average annual number of sets in the waters northeast of the closed areas was $48 \pm 12$, while during 2009, 2012, and 2013, the annual average was $136 \pm 5$ sets, an almost 3-fold increase in effort after 2008.

The spatial density of VMS vessel positions for fishers carrying reef fish permits and a bottom longline endorsement indicates there is spatial overlap with a portion of this fishery and the GoM Bryde's whale BIA (Fig. 1d). Additionally, reef fish or large pelagics longline fishers who also carry a shark-directed permit show VMS spatial density distributions which overlap with the GoM Bryde's whale BIA. This suggests the potential for interactions between GoM Bryde's whales and bottom longline gear within the BIA.

Combining logbook and observer program data provides information on how many bottom longline sets may be occurring within the BIA each year. From 2007 to 2015, bottom longline logbooks indicate an annual average of $21531 \pm 4890$ sets throughout the GoM (range: 13495-27877 $\mathrm{yr}^{-1}$ ). A subset of these bottom longline sets were observed by the reef fish fishery observer program, and the percent observed varied substantially between years (mean: $5.3 \pm$ $4.4 \%$; range: $0.4-11.5 \%$ ). In total, 9096 sets were observed throughout the GoM from 2007 to 2015, with an average of $1011 \pm 799$ observed sets per year (range: $110-2335$ sets $\mathrm{yr}^{-1}$ ). A total of 718 observed sets occurred within the BIA from 2007 to 2015, averaging $80 \pm 67$ observed sets within the BIA per year. Dividing the annual number of observed sets in the BIA by the annual proportion of observed sets to total logged sets throughout the GoM indicates an estimated $1533 \pm 961$ total bottom longline sets $\mathrm{yr}^{-1}$ occurring within the BIA (range: 507-3094 $\mathrm{yr}^{-1}$ ), assuming observer coverage was spatially random throughout the GoM each year.

Throughout the eastern GoM, totals of 2498 and 3982 sets were observed by the shark fishery observer program during the periods 1994-2004 and 2005-2015, respectively. Of these, only 25 shark sets were observed within the BIA over $7 \mathrm{~d}$ during the 11 yr period from 1994 to 2004. No observed sets occurred in the BIA from 2005 to 2015.

\section{DISCUSSION}

The northeastern GoM shelf break appears to be the current primary habitat for the GoM Bryde's whale. The GoM Bryde's whale population was first 'discovered' in the early 1990s when systematic sur- veys of the shelf break region and oceanic waters began (Hansen et al. 1995, Mullin \& Hansen 1999). Prior to that time, there were few sightings of baleen whales in the GoM, and it was not clear whether those that were sighted routinely inhabited the GoM or were accidentals or migrants (Fritts et al. 1983, Jefferson \& Schiro 1997). By the early 1990s, oil and gas infrastructure was already well developed across the continental shelf west of the BIA (Adams et al. 2004, BSEE 2017; data can be downloaded from https://www.data.boem.gov/Mapping/Files/platform. zip). Since 1992, a significant amount of ship-based visual survey effort has been conducted throughout the US waters of the GoM, and GoM Bryde's whale sightings have almost exclusively occurred along the northeastern shelf break. Sightings were made in all seasons, indicating a year-round presence in this area. While $10 \%$ of SEFSC ship-based survey effort between 1992 and 2015 occurred within the BIA identified by LaBrecque et al. (2015), $97 \%$ of sightings occurred in this area, with a few animals found just beyond the edges in waters out to $350 \mathrm{~m}$ depth or to the northwest. Only 1 sighting occurred west of the Mississippi River Delta, in similar water depths.

The satellite-tagged GoM Bryde's whale spent the entire $33 \mathrm{~d}$ that the tag transmitted within or just beyond the edges of the BIA, with $87.5 \%$ of its time spent in a $1084 \mathrm{~km}^{2}$ area. This strong site fidelity over the 1 mo period suggests that there were sufficient resources in this area at this time for this whale and offers further evidence that the northeast GoM shelfbreak waters represent important habitat for GoM Bryde's whales. As these data are only from 1 animal over a 1 mo period and the tag did not stay on across multiple seasons, it is not possible to determine whether this whale or other GoM Bryde's whales spend time outside of the northeast shelfbreak region and whether seasonal movements occur. Further satellite tagging efforts to increase sample size and cover other seasons could help answer these questions.

The kinematic-tagged GoM Bryde's whale exhibited a stereotyped dive behavior over $3 \mathrm{~d}$ in which deep foraging dives with lunges occurred near the seafloor during daylight hours and shallow dives or resting periods occurred during nighttime. An increasing trend in dive depth during the morning and a decreasing trend in dive depth at night suggest that the animal was following diel vertically migrating organisms that cluster at the seafloor during daylight and rise to the surface at night. These data are from only one tagged whale over a $3 \mathrm{~d}$ period and must be interpreted with caution. However, this tagging 
event provides the first and only data available on GoM Bryde's whale diving behavior, and this one whale represents $3 \%$ of the small population. Additionally, this is the longest reported tag deployment on any individual Bryde's whale (Madeira Island: $\mathrm{n}=$ 2 tagged, max duration $=14.53 \mathrm{~h}$, Alves et al. 2010; New Zealand: $\mathrm{n}=7$ tagged, $\max$ duration $=20.23 \mathrm{~h}$, Constantine et al. 2015) and is therefore a significant event. The tag data show highly consistent diel behavior over a period of $2.7 \mathrm{~d}$. It is not unreasonable to conclude that this behavior is representative of the GoM Bryde's whale population, as other tagged baleen whales similarly exhibit stereotypical diel dive behaviors related to foraging and prey distribution. For example, a tagging study of 7 coastal Bryde's whales in the Hauraki Gulf, New Zealand, a semi-enclosed bay with average water depths of $50 \mathrm{~m}$, found that deeper dives to $35 \mathrm{~m}$ depths occurred throughout the daytime and shallower dives of $14 \mathrm{~m}$ or less occurred throughout the nighttime (Constantine et al. 2015). Similarly, several studies found that blue whales Balaenoptera musculus in pelagic waters dove deeper during the day than at night, likely while foraging on krill (Croll et al. 1998, Calambokidis et al. 2007, Oleson et al. 2007). Additionally, a diel pattern of deep night dives and shallow daytime dives was found for 2 associated Bryde's whales likely foraging on krill in pelagic waters in the eastern North Atlantic off Madeira Island (Alves et al. 2010) and for humpback whales Megaptera novaeangliae likely foraging on sand lance (Ammodytidae) along the bottom at Stellwagen Bank in the western North Atlantic (Friedlaender et al. 2009). Further tagging research is needed to increase the sample size and determine whether the documented dive behavior is representative of the GoM Bryde's whale population.

\section{Vessel collision risk}

The major factors affecting the incidence and severity of vessel collisions are whale diving behavior, the levels of shipping traffic, the overlap between whale spatial distribution and shipping lanes, and the size and speed of the vessels. Whales that spend a greater proportion of time near the surface are at greater risk of ship strikes (Constantine et al. 2015). The GoM Bryde's whale tagged in this study spent $70 \%$ of its time within $15 \mathrm{~m}$ of the surface, making it vulnerable to ship strikes, given the average draft of larger vessels that transit the area. Further, the tagged whale spent $88 \%$ of nighttime hours, when whales will be less visible to vessels, within these shallow depths. If other GoM Bryde's whale individuals exhibit a similar diving pattern, this behavior places the population at a substantial risk for collisions with vessels. This risk is greater when whales at the surface have limited ability to avoid vessel collisions, as has been found for North Atlantic right whales Eubalaena glacialis and blue whales (Nowacek et al. 2004, McKenna et al. 2015). Ship strike mortalities of blue whales have been increasing off California as the overlap between shipping traffic and whale distribution increases (Berman-Kowalewski et al. 2010), and these whales may similarly spend a substantial proportion of time near the surface ( $78 \%$ of time within $16 \mathrm{~m}$ of the surface, $\mathrm{n}=1$, Lagerquist et al. 2000).

The northern GoM is an area of considerably high ship traffic, which increases the chance of shipwhale collisions. In 2013, US GoM ports accounted for nearly $50 \%$ of total tonnage transported to and from US ports, with the ports of South Louisiana, LA, and Houston, TX, transporting nearly $20 \%$ of the total US tonnage (US Army Corps of Engineers 2015). Further, vessel traffic in the GoM is increasing, with the number of vessel calls doubling from 17200 in 2002 to 34700 in 2013 (www.marad.dot.gov/data statistics). The risk from vessel collisions may further increase upon completion of the Panama Canal expansion as freight transport is redistributed from the Pacific coast ports to those in the GoM and as the world's container fleet accounts for the expansion by increasing its capacity of larger, faster ships (Institute for Water Resources 2012), which are more likely to result in lethal outcomes for whales when collisions occur (Laist et al. 2001, Jensen \& Silber 2004, Vanderlaan \& Taggart 2007). While most of the GoM shipping traffic is concentrated near ports and throughout the northwestern GoM, several shipping lanes traverse through the currently known primary GoM Bryde's whale habitat (Fig. 1c), indicating the potential for interactions. There were a total of 1089 commercial vessel calls at the ports of Manatee, Tampa, and Panama City, FL, during 2013, including bulk cargo carriers, tankers, and general cargo carriers (US Army Corps of Engineers 2015), and a portion of these vessels transit the shipping lanes that cross the GoM Bryde's whale BIA. Additionally, a shipping lane for tug and towing vessels transits between Crystal River, FL, and Louisiana (NOAA OCM 2015).

It is uncertain how great a risk vessel collisions present to GoM Bryde's whales. Only 1 GoM Bryde's whale vessel collision has been documented to date; however, the number of reported ship strikes is likely 
underestimated. If GoM Bryde's whales have carcass recovery rates similar to those estimated for other offshore GoM cetaceans, with $98-99.6 \%$ unrecovered (e.g. Williams et al. 2011), then most ship-struck GoM Bryde's whales likely would go undetected. Ship strikes are underestimated even for more commonly reported coastal species, such as right whales and humpback whales (Jensen \& Silber 2004), which have higher carcass recovery rates than those inhabiting offshore waters (e.g. Garshelis 1997, Williams et al. 2011, Wells et al. 2015). Further, the extended distance that carcasses of offshore species such as GoM Bryde's whales must drift to reach shore makes it less likely that they will be in fresh enough condition to determine cause of death. The vessel-struck GoM Bryde's whale in 2009 did not drift in but was brought in on the bow of a ship and was therefore fresh enough to determine cause of death. Given the small population size and the distance of their primary habitat from shore, GoM Bryde's whale mortalities will rarely be documented, and the likelihood of documenting a ship-struck whale will be even lower.

\section{Fishery interaction risk}

The degree of risk from direct fishery interactions is a function of the degree of spatial overlap between fishing effort and whale habitat, whale size and behavior, and the likelihood that an interaction will result in serious injury or mortality for a specific gear type (Benjamins et al. 2012). Fishing effort within the GoM Bryde's whale habitat is low compared to the rest of the US waters of the GoM. Effort from 3 of the largest Gulf fisheries (the shrimp fishery, the menhaden fishery, and the shallow-water portion of the reef fish fishery) occurs inshore of the $100 \mathrm{~m}$ isobath (Scott-Denton et al. 2011, 2012, NMFS 2013). In the large pelagics longline fishery, another major GoM fishery, fishing effort mainly begins beyond the $300 \mathrm{~m}$ isobath. This distribution in commercial fishery activity results in a hiatus in primary fishing effort in waters between 100 and $300 \mathrm{~m}$, which appears to be the preferred habitat for the GoM Bryde's whale in the northeastern GoM.

However, 2 fisheries, the deep-water portion of the reef fish fishery and occasionally the large pelagics longline fishery, do regularly fish within these waters (Fig. 1d). Bottom and pelagic longline gear pose a known entanglement threat to cetaceans in US waters, including minke $B$. acutorostrata, humpback, and Bryde's whales (Garrison 2007, Andersen et al. 2008, Forney et al. 2011, Waring et al. 2015). While pelagic longlines pose an entanglement threat to most cetaceans since their mainline gear occurs in the upper portions of the water column where cetaceans commonly occur (Andersen et al. 2008), bottom longline gear poses an entanglement threat (www.nmfs. noaa.gov/pr/interactions/gear/) mainly to cetaceans that feed along the bottom where the mainlines occur. In general, smaller whales, such as minke, Bryde's, and Omura's whales $B$. omurai, as well as juveniles and calves, are more likely to suffer serious injury or mortality from entanglements than larger whales for a given gear type and line strength (Benjamins et al. 2012, Reeves et al. 2013, Knowlton et al. 2016).

Considering the spatial overlap of the deep-water portion of the bottom longline reef fish fishery with GoM Bryde's whale habitat, the GoM Bryde's whale dive behavior documented in this study, and the level of fishing effort, the bottom longline reef fish fishery may pose an entanglement threat to GoM Bryde's whales. The deep-water portion of the GoM reef fish bottom longline fishery operates year-round, targeting yellowedge grouper Hyporthodus flavolimbatus, tilefish (Malacanthidae), and sharks (Elasmobranchii) in the deeper waters from 100 to $300 \mathrm{~m}$, and typically sets bottom longline gear during daytime (Scott-Denton et al. 2011). The tagged GoM Bryde's whale appears to have foraged near or along the bottom during daylight hours (Fig. 2), possibly foraging on diel-vertical-migrating schooling bait fish that form tight aggregations at the bottom during the day (e.g. Tershy 1992, Kato 2002). If this dive behavior is common throughout the population, GoM Bryde's whales' risk of encountering and becoming entangled in bottom longline mainlines is increased. There may be substantial effort from this fishery within the BIA with an estimated range of 507 to 3094 sets $\mathrm{yr}^{-1}$ in the BIA from 2007 to 2015 (mean $1533 \pm 961$ ). No GoM Bryde's whale entanglements in this fishery have been observed to date; however, observer coverage of this fishery is low, averaging $5.5 \%$, and interactions would be rare given the small population size of the whales, so there could still be a substantial risk from this fishery. The GoM shark fishery also uses bottom longline gear, although most effort occurs inshore of the GoM Bryde's whale habitat and therefore poses a lower risk.

The large pelagics longline fishery may pose an entanglement risk, considering the spatial overlap of the fishery and the GoM Bryde's whale habitat, and the kinematic-tagged whale's diel dive behavior, although levels of pelagic longline fishing effort within the GoM Bryde's whale habitat are relatively low. The GoM large pelagics longline fishery operates 
year-round throughout most of the US GoM waters deeper than $300 \mathrm{~m}$, and fishes at depths between 12 and $36.6 \mathrm{~m}$, targeting tuna (Scrombridae) during deeper daytime sets and swordfish Xiphias gladius during shallower nighttime sets (Waring et al. 2014). The tagged GoM Bryde's whale made repeated deep dives throughout the day and appeared to rest and make shallow dives during the night. If this diel dive behavior is common within the population, the whales have potential to interact with the pelagic longline gear during the day as they transit through the water column between the seafloor and the surface, and may additionally have the potential to interact with shallower set nighttime gear as they rest within $15 \mathrm{~m}$ of the surface during the night. No confirmed GoM Bryde's whale entanglements have been observed in this fishery, and the pelagic longline fishery has a high level of coverage $(20 \%)$ throughout the GoM, with rare cetacean interactions (Garrison \& Stokes 2014), so the risk posed by this fishery may be low. However, some whale sightings occurred in deeper waters beyond the BIA $300 \mathrm{~m}$ bounds where there is higher longline effort, and within the Bryde's whale habitat only $5 \%$ of sets were observed. Given the small population size of the whales, interactions are expected to be rare, particularly outside of their habitat, and rare interactions are more challenging to document with lower levels of observer coverage.

\section{Management considerations}

The reasons why GoM Bryde's whales inhabit a restricted area in the northeastern GoM and have such low population numbers are unknown. The US waters of the GoM are highly industrialized, and impacts from anthropogenic activities may include chronic habitat degradation, single catastrophic events, and small-scale incremental impacts over time. Oil and gas extraction and exploration in the GoM west of $88^{\circ} \mathrm{W}$ are higher than anywhere else in the US (NOAA NOS 2011). There are more than 3500 active oil and gas platforms and more than $40000 \mathrm{~km}$ of oil and gas pipeline in the northcentral and northwestern GoM, but no active platforms in the northeastern GoM Bryde's whales' primary habitat (NOAA NOS 2011). The high levels of activity may have modified or degraded historical GoM Bryde's whale habitat in GoM waters west of $88^{\circ} \mathrm{W}$. Oil platforms act as artificial reefs and modify the natural biota; highspeed service vessel traffic increases noise levels and risk of vessel collisions; drilling increases noise levels and risk of oil and leaks, and seismic surveying for exploration and oil field maintenance increases noise levels. Ocean noise pollution is increasingly being understood as a problem that not only directly injures whales in close proximity to sound sources, but also degrades their habitat over widespread regions with potential for population level impacts (Francis \& Barber 2013). Average ambient noise levels at low frequencies in the northern GoM are among the highest measured in the world's oceans, and seismic airgun surveys for energy exploration and shipping traffic dominate these high noise levels (Estabrook et al. 2016, Wiggins et al. 2016). Notably, the primary GoM Bryde's whale habitat near the De Soto Canyon is quieter than other sites in the northern GoM due to lower levels of shipping and seismic survey activity (Estabrook et al. 2016, Wiggins et al. 2016), but noise levels are still high compared to current and historical levels in other baleen whale habitats in US waters (e.g. McDonald et al. 2006). The high levels of noise and other oil and gas industrial activities in the GoM west of $88^{\circ} \mathrm{W}$ may have led to a range contraction and associated decrease in abundance for the GoM Bryde's whales (Rosel \& Wilcox 2014). Single catastrophic events do not occur frequently, but when they do, they can have major impacts on small populations of whales, especially those with a restricted habitat. The catastrophic Deepwater Horizon oil spill of 2010 was estimated to impact $48 \%$ of the GoM Bryde's whale habitat and to have led to a $22 \%$ population decline in the GoM Byrde's whale population (DWH MMIQT 2015); it is estimated the population will take $69 \mathrm{yr}$ to recover from these losses (DWH MMIQT 2015), and there is potential for continuing mortalities and reduced fecundity for decades (e.g. Matkin et al. 2008). Lastly, activities which result in single mortalities over time, such as collisions with vessels and entanglements in fishery gear, can incrementally chip away at a population, and this can be particularly devastating for small populations which cannot quickly replace those losses. The loss of a single reproductive female can have devastating impacts on very small populations, as has been described for impacts on North Atlantic right whales (Fujiwara \& Caswell 2001). If the behaviors exhibited by the kinematic-tagged whale are common for female whales with their young, the risk of vessel collisions is particularly concerning considering the vulnerability of these members and their value to the population. The one documented ship strike involving a GoM Bryde's whale was a lactating female (NOAA MMHSRP 2015). It is important to understand how frequently these single interactions occur to evaluate their population level impacts. In light of the 
recent catastrophic losses from the Deepwater Horizon oil spill, minimizing single losses from vessel collisions and fishery interactions can aid in post-spill restoration efforts.

Historically, the north central GoM was likely part of the GoM Bryde's whale habitat (e.g. Reeves et al. 2011), but there is little evidence the whales currently attempt to inhabit those highly industrialized waters where they would have high risks of interactions. There has been substantial ship-based (Fig. 1a) and aerial survey effort in the northwestern GoM, but there were only 2 sightings in the early 1990s. During a ship-based survey in 1992, a group of 2 Bryde's or sei whales was sighted in water depths similar to those of the northeastern GoM Bryde's whale habitat (Fig. 1b). Additionally, in 1993, a SEFSC aerial survey spotted a single Bryde's or sei whale in the same region (Hansen et al. 1996). Further, 16 verified Bryde's whale strandings were documented between 1954 and 2015 in the northern GoM, of which 8 occurred along Louisiana shores, mostly in eastern Louisiana (Jefferson 1995, NOAA MMHSRP 2015); however, the origin of these sick or dead whales is unknown. Both the number of vessel transits and fishery effort, including bottom and pelagic longlines, are high in the $100-300 \mathrm{~m}$ waters of the GoM west of $88^{\circ} \mathrm{W}$ compared to the northeastern region. Major shipping lanes converge and vessels transit along the $200 \mathrm{~m}$ isobath in the northwestern Gulf, with $5 \%$ of waters in the 100-300 m depth range having a minimum of 500 to 1500 or more transits $\mathrm{yr}^{-1}$ ( 2 to 5 or more $\mathrm{d}^{-1}$; Fig. 1). The high levels of commercial shipping traffic and commercial fishing effort as well as the high levels of oil and gas exploration and extraction in the northwestern GoM may have reduced the suitability of this historical habitat for GoM Bryde's whales, and the current De Soto Canyon area may be remnant habitat. In addition to the high productivity of the canyon region, it has some of the lowest levels of anthropogenic activity in the US waters of the GoM, which may explain why GoM Bryde's whales are able to remain there.

To develop a conservation recovery program for GoM Bryde's whales to improve population trajectory and habitat size, the accurate identification and removal of anthropogenic threats is essential (e.g. Crees et al. 2016). Numerous mitigation measures can be enacted to decrease the risk of vessel collisions and fisheries interaction for GoM Bryde's whales. Due to the lower amount of industrial activity within the current known GoM Bryde's whale habitat compared to other regions in the GoM, this may be an ideal location for setting up geospatial mitigation measures, such as a well-designed marine protected area (MPA) (e.g. Agardy et al. 2011, Hoyt 2011, Maxwell et al. 2014) that manages shipping and fishing activity, with large benefits possible for GoM Bryde's whales and relatively low impacts to the shipping and fishing industries. Pelagic longline fishing is already banned in the De Soto Canyon closed areas that partially overlap the GoM Bryde's whale habitat, and these closed areas potentially could be expanded to cover more area and other activities. In addition to shipping and longline activity, an MPA could also protect the whales from other GoM industrial activities such as oil and gas extraction and exploration to reduce the potential impacts of oil spills, oil platform service vessel traffic, and seismic survey noise. Ship speed reduction rules and vessel re-routing have been effective at reducing North Atlantic right whale deaths from vessel collisions (Lagueux et al. 2011, Laist et al. 2014, van der Hoop et al. 2015) and could be implemented in the GoM Bryde's whale habitat to reduce the risk to the whales. This will be particularly important as larger, faster Panamax vessels increasingly transit the GoM. Increasing observer coverage within GoM Bryde's whale habitat to $100 \%$ for pelagic longline and bottom longline fishers operating there could provide the necessary data to determine whether rare fishery interactions occur. If they do, gear modifications (e.g. Knowlton et al. 2016) and geospatial mitigation measures (e.g. Asaro 2012) could be considered. For each of these mitigation techniques, enacting measures within the known GoM Bryde's whale habitat will protect the whales in their primary habitat and would be an important step in preventing further population decline. However, for the population to grow, expanded habitat protection will also be important to support range expansion (Crees et al. 2016). More research is needed to determine the preferred prey of GoM Bryde's whales and to identify regions with high prey densities to support the whales, such as in the northwestern and southern GoM historical habitat. Once appropriate habitat is identified, the described mitigation measures could additionally be enacted as needed in high-quality habitat throughout the wider GoM to facilitate population growth and range expansion.

\section{CONCLUSIONS}

GoM Bryde's whales may be at risk of vessel collisions and bottom longline gear entanglement based on the dive behavior documented from a kinematic- 
tagged GoM Bryde's whale over $3 \mathrm{~d}$ and on the spatial distribution of the population, a satellite-tagged GoM Bryde's whale, major vessel traffic lanes, and the deep water bottom longline fishery. Small populations are particularly vulnerable even when anthropogenic interactions are rare, and should an interaction occur, there is a low likelihood of observing it with sparse stranding and observer program data (e.g. Knowlton et al. 2012). As of 2009, with 33 individuals, this population is similar in size to the northeast Pacific population of North Pacific right whale E. japonica, one of the most critically endangered large whale populations in the world (Muto et al. 2016), and to the vaquita Phocoena sinus, which is thought to be on the verge of extinction (Taylor et al. 2016). Considering that GoM Bryde's whales were the most impacted offshore cetaceans during the Deepwater Horizon oil spill in 2010 with an estimated $22 \%$ population decline, they would certainly benefit from every possible reduction in anthropogenic mortality. Overall, there are low to moderate levels of anthropogenic activity, including vessel traffic and fishery activity, within the current GoM Bryde's whale habitat in the northeastern GoM compared to the rest of the US waters of the GoM, and this factor may partially explain why the population remains there. Noise levels in the BIA are lower than in other regions of the GoM, but are higher than those in historical whale habitats, and the potential impacts of anthropogenic noise on GoM Bryde's whales need further study. Mitigation measures to reduce the potential for anthropogenic mortality and habitat degradation in these waters would likely impact a relatively small portion of these industries and potentially provide a large benefit for the very small and unique GoM Bryde's whales. Further study of habitat requirements will be necessary to extend mitigation measures to a broader region to allow habitat expansion.

Acknowledgements. We thank the GU1505 field team including Jesse Wicker, Katrina Ternus, Kevin Barry, Mark Grace, Lauren Noble, Gina Rappucci, Errol Ronje, and Carrie Sinclair, and all field and ship crew members who collected the sightings data during NOAA SEFSC cruises from 1992 to 2015. Elizabeth Scott-Denton, John Carlson, Ken Keene, Matt Maiello, Kevin McCarthy, Carlos Rivero, and Steve Turner provided fishery data used to evaluate fishery spatial distributions, effort, and protected species interactions and also engaged in discussions to help us better understand the fisheries. Kyle Ward provided the AIS data and helped us understand the nuances of the data collection. This work benefitted from discussions with Peter Corkeron, Laura Engleby, Deborah Epperson, and Barbara Taylor. This manuscript was improved by the thoughtful suggestions of 2 anonymous reviewers. Survey data and biopsies were col- lected under MMPA permit numbers 738, 779-1339, 7791633, and 14450 issued to the NMFS SEFSC. Satellite tagging was conducted under NMFS Office of Protected Resources Permit No. 779-1633 issued to the SEFSC. Suction-cup tagging was conducted under NMFS permit 17312 issued to the Scripps Institution of Oceanography. Surveys were supported in part by interagency agreements with NOAA and the BOEM (Minerals Management Service, Gulf of Mexico Region: nos. 16197 and 15958; and no. M10PG 00075), the US Navy (no. NEC-11-009; and under Chief of Naval Operations, Environmental RDT\&E Program Code N45), and the US Geological Survey, Biological Resources Division (no. 1445-IA09-96-0009).

\section{LITERATURE CITED}

Adams CM, Hernandez E, Cato JC (2004) The economic significance of the Gulf of Mexico related to population, income, employment, minerals, fisheries and shipping. Ocean Coast Manag 47:565-580

* Agardy T, di Sciara GN, Christie P (2011) Mind the gap: addressing the shortcomings of marine protected areas through large scale marine spatial planning. Mar Policy 35:226-232

Alves F, Dinis A, Cascão I, Freitas L (2010) Bryde's whale (Balaenoptera brydei) stable associations and dive profiles: new insights into foraging behavior. Mar Mamm Sci 26:202-212

Andersen MS, Forney KA, Cole TV, Eagle T and others (2008) Differentiating serious and non-serious injury of marine mammals: Report of the serious injury technical workshop, 10-13 Sep 2007, Seattle, Washington. NOAA Tech Memo NMFS-OPR 39. NOAA OPR, Silver Spring, MD

* Andrews RD, Pitman RL, Ballance LT (2008) Satellite tracking reveals distinct movement patterns for Type $\mathrm{B}$ and Type C killer whales in the southern Ross Sea, Antarctica. Polar Biol 31:1461-1468

*Asaro MJ (2012) Geospatial analysis of management areas implemented for protection of the North Atlantic right whale along the northern Atlantic coast of the United States. Mar Policy 36:915-921

Barlow J (1995) The abundance of cetaceans in California waters. 1. Ship surveys in summer and fall of 1991. Fish Bull 93:1-14

*Benjamins S, Ledwell W, Huntington J, Davidson AR (2012) Assessing changes in numbers and distribution of large whale entanglements in Newfoundland and Labrador, Canada. Mar Mamm Sci 28:579-601

Berkenbusch K, Abraham ER, Torres L (2013) New Zealand marine mammals and commercial fisheries. New Zealand Aquatic Environment and Biodiversity Report No. 119. Ministry for Primary Industries, Wellington

Berman-Kowalewski M, Gulland FM, Wilkin S, Calambokidis J and others (2010) Association between blue whale (Balaenoptera musculus) mortality and ship strikes along the California coast. Aquat Mamm 36:59-66

Blaylock RA, Hain JW, Hansen LJ, Palka DL, Waring GT (1995) U.S. Atlantic and Gulf of Mexico marine mammal stock assessments. NOAA Tech Memo NMFS-SEFSC363. NOAA, SEFSC, Miami, FL

BOEM, NOAA (Bureau of Ocean Energy Management, National Oceanic and Atmospheric Administration) (2015) Commercial vessel density October 2009-2010 AIS National. marinecadastre.gov/data (accessed 8 October 2015) 
BSEE (Bureau of Safety and Environmental Enforcement Gulf of Mexico OCS Region) (2017) Drilling platforms. marinecadastre.gov/data (accessed 13 March 2017)

Buckland ST, Anderson DR, Burnham KP, Laake JL (1993) Distance sampling: estimating abundance of biological populations. Chapman and Hall, London

Burnham KP, Anderson DR, Laake JL (1980) Estimation of density from line transect sampling of biological populations. Wildl Monogr 72:3-202

Calambokidis J, Schorr GS, Steiger GH, Francis J and others (2007) Insights into the underwater diving, feeding, and calling behavior of blue whales from a suction-cupattached video-imaging tag (Crittercam). Mar Technol Soc J 41:19-29

Campbell-Malone R, Barco SG, Daoust PY, Knowlton AR, McLellan WA, Rotstein DS, Moore MJ (2008) Gross and histologic evidence of sharp and blunt trauma in North Atlantic right whales (Eubalaena glacialis) killed by vessels. J Zoo Wildl Med 39:37-55

Carretta JV, Forney KA, Lowry MS, Barlow J, Baker J, Hanson B, Muto MM (2008) U.S. Pacific marine mammal stock assessments: 2007. NOAA Tech Memo NMFSSWFSC-414. NOAA SWFSC, La Jolla, CA

Carretta JV, Wilkin SM, Muto MM, Wilkinson K (2013) Sources of human-related injury and mortality for US Pacific west coast marine mammal stock assessments, 2007-2011. NOAA Tech Memo NMFS-SWFSC-514. NOAA SWSFC, La Jolla, CA

Carretta JV, Wilkin SM, Muto MM, Wilkinson K, Rusin J (2014) Sources of human-related injury and mortality for U.S. Pacific west coast marine mammal stock assessments, 2008-2012. NOAA Tech Memo NMFS-SWFSC533. NOAA, SWFSC, La Jolla, CA

Carrillo M, Ritter F (2010) Increasing numbers of ship strikes in the Canary Islands: proposals for immediate action to reduce risk of vessel-whale collisions. J Cetacean Res Manag 11:131-138

Cassoff RM, Moore KM, McLellan WA, Barco SG, Rotstein DS, Moore MJ (2011) Lethal entanglement in baleen whales. Dis Aquat Org 96:175-185

Constantine R, Johnson M, Riekkola L, Jervis S and others (2015) Mitigation of vessel-strike mortality of endangered Bryde's whales in the Hauraki Gulf, New Zealand. Biol Conserv 186:149-157

Crees JJ, Collins AC, Stephenson PJ, Meredith HMR and others (2016) A comparative approach to assess drivers of success in mammalian conservation recovery programs. Conserv Biol 30:694-705

Croll DA, Tershy BR, Hewitt RP, Demer DA and others (1998) An integrated approach to the foraging ecology of marine birds and mammals. Deep Sea Res II 45: 1353-1371

DWH MMIQT (Deepwater Horizon Marine Mammal Injury Quantification Team) (2015) Models and analyses for the quantification of injury to Gulf of Mexico cetaceans from the Deepwater Horizon oil spill. DWH Marine Mammal NRDA Technical Working Group Report. https://www. doi.gov/deepwaterhorizon/adminrecord

Estabrook BJ, Ponirakis DW, Clark CW, Rice AN (2016) Widespread spatial and temporal extent of anthropogenic noise across the northeastern Gulf of Mexico shelf ecosystem. Endang Species Res 30:267-282

Forney KA, Barlow J, Moto MM, Lowry M and others (2000) U.S. Pacific marine mammal stock assessments: 2000. NOAA Tech Memo NMFS-SWFSC-300. NOAA SWFSC,
La Jolla, CA

Forney KA, Kobayashi DR, Johnston DW, Marchetti JA, Marsik MG (2011) What's the catch? Patterns of cetacean bycatch and depredation in Hawaii-based pelagic longline fisheries. Mar Ecol 32:380-391

*Francis CD, Barber JR (2013) A framework for understanding noise impacts on wildlife: an urgent conservation priority. Front Ecol Environ 11:305-313

Friedlaender AS, Hazen EL, Nowacek DP, Halpin PN and others (2009) Diel changes in humpback whale Megaptera novaeangliae feeding behavior in response to sand lance Ammodytes spp. behavior and distribution. Mar Ecol Prog Ser 395:91-100

Fritts TH, Irvine A, Jennings R, Collum L, Hoffman W, McGehee M (1983) Turtles, birds, and mammals in the northern Gulf of Mexico and nearby Atlantic waters. An overview based on aerial surveys of OCS areas, with emphasis on oil and gas effects. Museum of Southwestern Biology, New Mexico University, Albuquerque, NM

Fujiwara M, Caswell H (2001) Demography of the endangered North Atlantic right whale. Nature 414:537-541

Garrison LP (2007) Interactions between marine mammals and pelagic longline fishing gear in the US Atlantic Ocean between 1992 and 2004. Fish Bull 105:408-417

Garrison LP (2016) Abundance of marine mammals in waters of the U.S. Gulf of Mexico during summer 2009. PRD-2016-09. NOAA, SEFSC, Miami, FL

Garrison LP, Stokes L (2014) Estimated bycatch of marine mammals and turtles in the U.S. Atlantic pelagic longline fleet during 2013. NOAA Tech Memo NMFS-SEFSC667. NOAA SEFSC, Miami, FL

* Garshelis DL (1997) Sea otter mortality estimated from carcasses collected after the Exxon Valdez oil spill. Conserv Biol 11:905-916

Gloekner D, Turner S (2016) Coastal fisheries logbook data. US NOAA, NMFS, SEFSC, Miami, FL

* Goldbogen JA, Calambokidis J, Shadwick RE, Oleson EM, McDonald MA, Hildebrand JA (2006) Kinematics of foraging dives and lunge-feeding in fin whales. J Exp Biol 209:1231-1244

*Groom C, Coughran D (2012) Entanglements of baleen whales off the coast of Western Australia between 1982 and 2010: patterns of occurrence, outcomes and management responses. Pac Conserv Biol 18:203-214

Hale LF, Carlson JK (2007) Characterization of the shark bottom longline fishery, 2005-2006. NOAA Tech Memo NMFS-SEFSC-554. NOAA SEFSC, Panama City, FL

Hale LF, Gulak SJB, Carlson JK (2010) Characterization of the shark bottom longline fishery, 2009. NOAA Tech Memo NMFS-SEFSC-596. NOAA SEFSC, Panama City, FL

Hansen L, Mullin K, Roden C (1995) Estimates of cetacean abundance in the northern Gulf of Mexico from vessel surveys. Miami Laboratory Contribution No. MIA-94/9525. NOAA, SEFSC, Miami, FL

Hansen LJ, Mullin KD, Jefferson TA, Scott GP (1996) Distribution and abundance of cetaceans in the north-central and western Gulf of Mexico: final report. Volume II: Technical Report. Visual surveys aboard ships and aircraft. US Dept of the Interior, Minerals Management Service, Gulf of Mexico OCS Region, New Orleans, LA

Heyning J, Dahlheim M (1990) Strandings and incidental takes of gray whales. Paper Sc/a90/g2 presented to the IWC Scientific Committee special meeting on the assessment of gray whales, Seattle, WA 
Hoyt E (2011) Marine Protected Areas for whales, dolphins and porpoises: a world handbook for cetacean habitat conservation and planning. Earthscan, New York, NY

Institute for Water Resources (2012) U.S. port and inland waterways modernization: preparing for post-panamax vessels. U.S. Army Corps of Engineers, Alexandria, VA

Jefferson TA (1995) Distribution, abundance and some aspects of the biology of cetaceans in the offshore Gulf of Mexico. PhD thesis, Texas A\&M University, College Station, TX

Jefferson TA, Schiro AJ (1997) Distribution of cetaceans in the offshore Gulf of Mexico. Mammal Rev 27:27-50

Jensen AS, Silber GK (2004) Large whale ship strike database. US Department of Commerce, National Oceanic and Atmospheric Administration, Silver Spring, MD

Kato H (2002) Bryde's whales, Balaenoptera edeni and $B$. brydei. In: Perrin WF, Wursig B, Thewissen JGM (eds) Encyclopedia of marine mammals. Academic Press, San Diego, CA, p 171-177

Keene K, Beerkircher L (2015) SEFSC Pelagic Longline Observer Program Database. NOAA, NMFS, SEFSC, Miami, FL

Knowlton AR, Kraus SD (2001) Mortality and serious injury of northern right whales (Eubalaena glacialis) in the western North Atlantic Ocean. J Cetacean Res Manag 2: 193-208

Knowlton AR, Hamilton PK, Marx MK, Pettis HM, Kraus SD (2012) Monitoring North Atlantic right whale Eubalaena glacialis entanglement rates: a $30 \mathrm{yr}$ retrospective. Mar Ecol Prog Ser 466:293-302

Knowlton AR, Robbins J, Landry S, McKenna HA, Kraus SD, Werner T (2016) Implications of fishing rope strength on the severity of large whale entanglements. Conserv Biol 30:318-328

Kraus SD, Brown MW, Caswell H, Clark CW and others (2005) North Atlantic right whales in crisis. Science 309: 561-562

LaBrecque E, Curtice C, Harrison J, Van Parijs SM, Halpin PN (2015) Biologically Important Areas for cetaceans within U.S. waters-Gulf of Mexico region. Aquat Mamm 41(Spec Issue):30-38

Lagerquist BA, Stafford KM, Mate BR (2000) Dive characteristics of satellite-monitored blue whales (Balaenoptera musculus) off the central California coast. Mar Mamm Sci 16:375-391

Lagueux KM, Zani MA, Knowlton AR, Kraus SD (2011) Response by vessel operators to protection measures for right whales Eubalaena glacialis in the southeast US calving ground. Endang Species Res 14:69-77

Laist DW, Knowlton AR, Mead JG, Collet AS, Podesta M (2001) Collisions between ships and whales. Mar Mamm Sci 17:35-75

Laist DW, Knowlton AR, Pendleton D (2014) Effectiveness of mandatory vessel speed limits for protecting North Atlantic right whales. Endang Species Res 23:133-147

Lloyd B (2003) Potential effects of mussel farming on New Zealand's marine mammals and seabirds: a discussion paper. Department of Conservation, Wellington

Maiello M (2015) SEFSC large pelagic logbook set survey database. US National Oceanic Atmospheric Administration, National Marine Fisheries Service, Southeast Fisheries Science Center, Miami, FL

Matkin CO, Saulitis EL, Ellis GM, Olesiuk P, Rice SD (2008) Ongoing population-level impacts on killer whales Orcinus orca following the 'Exxon Valdez' oil spill in Prince William Sound, Alaska. Mar Ecol Prog Ser 356:269-281

*Maxwell SM, Ban NC, Morgan LE (2014) Pragmatic approaches for effective management of pelagic marine protected areas. Endang Species Res 26:59-74

McDonald MA, Hildebrand JA, Wiggins SM (2006) Increases in deep ocean ambient noise in the Northeast Pacific west of San Nicolas Island, California. J Acoust Soc Am 120:711-718

*McKenna MF, Calambokidis J, Oleson EM, Laist DW, Goldbogen JA (2015) Simultaneous tracking of blue whales and large ships demonstrates limited behavioral responses for avoiding collision. Endang Species Res 27: 219-232

Mead JG (1977) Records of sei and Bryde's whales from the Atlantic coast of the United States, the Gulf of Mexico, and the Caribbean. Rep Int Whal Comm Spec Issue 1: 113-116

Meÿer M, Best P, Anderson-Reade M, Cliff G, Dudley S, Kirkman S (2011) Trends and interventions in large whale entanglement along the South African coast. Afr J Mar Sci 33:429-439

Moazzam M, Nawaz R (2014) By-catch of tuna gillnet fisheries of Pakistan: a serious threat to non-target, endangered and threatened species. J Mar Biol Assoc India 56: 85-90

Mullin KD (2007) Abundance of cetaceans in the oceanic Gulf of Mexico based on 2003-2004 ship surveys. NMFS, Southeast Fisheries Science Center, Pascagoula, MS

Mullin KD, Fulling GL (2004) Abundance of cetaceans in the oceanic northern Gulf of Mexico, 1996-2001. Mar Mamm Sci 20:787-807

Mullin K, Hansen L (1999) Marine mammals of the northern Gulf of Mexico. In: Kumpf H, Steidinger K, Sherman K (eds) Gulf of Mexico: a large marine ecosystem. Blackwell Science, Malden, MA, p 269-277

Mullin KD, Hoggard W, Roden CL, Lohoefener RR, Rogers CM, Taggart B (1994) Cetaceans on the upper continental slope in the north-central Gulf of Mexico. Fish Bull 92: 773-786

Muto MM, Helker VT, Angliss RP, Allen BA and others (2016) Alaska marine mammal stock assessments, 2015. NOAA Tech Memo NMFS-AFSC-323. NOAA AFSC, Seattle, WA

NMFS (2013) SEDAR 32A stock assessment report - Gulf of Mexico menhaden. SEDAR, North Charleston, SC

NOAA MMHSRP (National Oceanic and Atmospheric Administration Marine Mammal Health and Stranding Response Program) (2015) National database. https:// mmhsrp.nmfs.noaa.gov/mmhsrp/ (accessed 15 September 2015)

NOAA NOS (National Ocean Service) (2011) The Gulf of Mexico at a glance: a second glance. US Dept of Commerce, Washington, DC

*NOAA OCM (Office for Coastal Management) (2015) 2013 tug and towing vessel density. https://coast.noaa.gov/ arcgis/rest/services/MarineCadastre/2013TugTowing VesselDensity/MapServer (accessed 3 May 2016)

Nowacek DP, Johnson MP, Tyack PL (2004) North Atlantic right whales (Eubalaena glacialis) ignore ships but respond to alerting stimuli. Proc R Soc B Biol Sci 271:227-231

Oleson EM, Calambokidis J, Burgess WC, McDonald MA, LeDuc CA, Hildebrand JA (2007) Behavioral context of call production by eastern North Pacific blue whales. Mar Ecol Prog Ser 330:269-284 
Read AJ, Drinker P, Northridge S (2006) Bycatch of marine mammals in U.S. and global fisheries. Conserv Biol 20: 163-169

Reeves RR, Lund JN, Smith T, Josephson EA (2011) Insights from whaling logbooks on whales, dolphins, and whaling in the Gulf of Mexico. Gulf Mex Sci 29:41-67

Reeves RR, McClellan K, Werner TB (2013) Marine mammal bycatch in gillnet and other entangling net fisheries, 1990 to 2011. Endang Species Res 20:71-97

Rivero C (2015) SEFSC VMS and Permit Data Warehouse. NOAA, NMFS, SEFSC, Miami, FL

Robbins J, Mattila D (2004) Estimating humpback whale (Megaptera novaeangliae) entanglement rates on the basis of scar evidence. Final report. Northeast Fisheries Science Center, Woods Hole, MA

Rosel PE, Wilcox LA (2014) Genetic evidence reveals a unique lineage of Bryde's whales in the northern Gulf of Mexico. Endang Species Res 25:19-34

Rosel PE, Corkeron PJ, Engleby L, Epperson D and others (2016) Status review of Bryde's whales (Balaenoptera edeni) in the Gulf of Mexico under the Endangered Species Act. NOAA Tech Memo NMFS-SEFSC-692. NOAA SEFSC, Lafayette, LA

Scott-Denton E, Cryer PF, Gocke JP, Harrelson MR and others (2011) Descriptions of the US Gulf of Mexico reef fish bottom longline and vertical line fisheries based on observer data. Mar Fish Rev 73:1-26

Scott-Denton E, Cryer PF, Duffy MR, Gocke JP and others (2012) Characterization of the U.S. Gulf of Mexico and South Atlantic penaeid and rock shrimp fisheries based on observer data. Mar Fish Rev 74:1-27

Taylor BL, Rojas-Bracho L, Moore J, Jaramillo-Legorreta A and others (2016) Extinction is imminent for Mexico's endemic porpoise unless fishery bycatch is eliminated. Conserv Lett, doi:10.1111/conl.12331

Tershy BR (1992) Body size, diet, habitat use, and social behavior of Balaenoptera whales in the Gulf of California. J Mammal 73:477-486

Thomas PO, Reeves RR, Brownell RL (2016) Status of the world's baleen whales. Mar Mamm Sci 32:682-734

US Army Corps of Engineers (2015) Principal ports of the United States. www.navigationdatacenter.us/data/data ppor.htm (accessed 11 August 2015)

Van der Hoop JM, Vanderlaan ASM, Cole TVN, Henry AG and others (2015) Vessel strikes to large whales before and after the 2008 Ship Strike Rule. Conserv Lett 8:24-32

Van Waerebeek K, Leaper R (2008) Second report of the

Editorial responsibility: Helene Marsh,

Townsville, Queensland, Australia
IWC vessel strike data standardisation working group. SC/ 60/BC5. International Whaling Commission, Santiago

*Van Waerebeek K, Baker AN, Félix F, Gedamke J and others (2007) Vessel collisions with small cetaceans worldwide and with large whales in the Southern Hemisphere, an initial assessment. Lat Am J Aquat Mamm 6:43-69

*Vanderlaan AS, Taggart CT (2007) Vessel collisions with whales: the probability of lethal injury based on vessel speed. Mar Mamm Sci 23:144-156

Waring GT, Josephson E, Maze-Foley K, Rosel PE (2012) U.S. Atlantic and Gulf of Mexico marine mammal stock assessments - 2011. NOAA Tech Memo NMFS-NE-221. NOAA, NEFSC, Woods Hole, MA

Waring GT, Josephson E, Maze-Foley K, Rosel PE (2014) U.S. Atlantic and Gulf of Mexico marine mammal stock assessments - 2013. NOAA Tech Memo NMFS-NE-228. NOAA, NEFSC, Woods Hole, MA

Waring GT, Josephson E, Maze-Foley K, Rosel PE (2015) U.S. Atlantic and Gulf of Mexico marine mammal stock assessments - 2014. NOAA Tech Memo NMFS-NE-231. NOAA, NEFSC, Woods Hole, MA

Waring GT, Josephson E, Maze-Foley K, Rosel PE (2016) U.S. Atlantic and Gulf of Mexico marine mammal stock assessments - 2015. NOAA Tech Memo NMFS-NE-238. NOAA, NEFSC, Woods Hole, MA

Wells RS, Allen JB, Lovewell G, Gorzelany J, Delynn RE, Fauquier DA, Barros NB (2015) Carcass recovery rates for resident bottlenose dolphins in Sarasota Bay, Florida. Mar Mamm Sci 31:355-368

* Western and Central Pacific Fisheries Commission (2012) Summary information on whale shark and cetacean interactions in the tropical WCPFC purse seine fishery. WCPFC8-2011-IP-01 (rev. 1). In: Western and Central Pacific Fisheries Commission (ed) SPC-OFP, Eighth regular session, Tumon, Guam, USA, 26-30 March 2012, p 12. www.wcpfc.int/conference-documents

Wiggins SM, Hall J, Thayre BJ, Hildebrand JA (2016) Gulf of Mexico low-frequency ocean soundscape dominated by airguns. J Acoust Soc Am 140:176-183

*Williams R, Gero S, Bejder L, Calambokidis J and others (2011) Underestimating the damage: interpreting cetacean carcass recoveries in the context of the Deepwater Horizon/BP incident. Conserv Lett 4:228-233

Yeung C (1999) Estimates of marine mammal and marine turtle bycatch by the U.S. Atlantic pelagic longline fleet in 1998. NOAA Tech Memo NMFS-SEFSC-430. NOAA, SEFSC, Miami, FL

Submitted: December 13, 2016; Accepted: April 20, 2017 Proofs received from author(s): June 8, 2017 